\title{
Small Cell Carcinoma Rectum With Liver Metastases: A Case Report
}

\author{
Dr.Ashfaque Mohammad ${ }^{1}$, Dr.Thangam Varghese ${ }^{2}$, Dr.Venkatesh Shanbag ${ }^{3}$, \\ Dr.Srikanth Soma ${ }^{4}$ \\ ${ }^{I}$ (Associate Professor,General surgery,Kasturba Medical College,Mangalore,Manipal University,India) \\ ${ }_{2}^{2}$ (Professor, General surgery,Kasturba Medical College,Mangalore,Manipal University,India) \\ ${ }_{3}^{3}$ (Assistant Professor, General surgery,Kasturba Medical College,Mangalore,Manipal University,India) \\ ${ }^{4}$ (Junior Resident,General surgery,Kasturba Medical College,Mangalore,Manipal University,India)
}

\begin{abstract}
Large bowel small cell cancers are extremely rare in presentation.Till date, approximately 100 cases have been reported in literature. Only three cases of small cell carcinoma of the rectum with liver metastasis have been published. We describe you a patient with multiple liver metastases from a primary in the rectum.The patient presented late with multiple,bilobar liver metastases unresectable at the time of diagnosis. Colonoscopy showed a rectal polyp ulcerated at its summit, from which a biopsy was taken. The biopsy revealed neuroendocrine carcinoma-small cell variant.The patient has been receiving chemotherapy for the same and has been asymptomatic till date.
\end{abstract}

Keywords: Extrapulmonary small cell cancer; Large liver metastasis; Neuroendocrine liver metastasis; Rectal cancer

\section{Introduction}

The incidence of neuroendocrine tumors is estimated to be 1 to 2 in 1,00,000 population.Majority of them arise sporadically.Most of the tumors are asymptomatic and non functioning at the time of presentation.

A 65 year old female presented to our hospital with the chief complaints of significant loss of weight and appetite for the past two months.The patient had no history of abdominal pain/distension,malaena/frank bleeding per rectum,jaundice,vomittings. There was no history of altered bowel habits or bladder disturbances.On abdominal examination,there was massive hepatomegaly extending $16 \mathrm{~cm}$ below the right costal margin.Upon per rectal examination,a $1 \mathrm{~cm}$ polyp was palpable $4 \mathrm{~cm}$ above the anal verge. All the blood investigations were within normal limits.

Ultrasound of the abdomen revealed gross hepatomegaly with multiple,bilobar metastases.So the patient was subjected for further evaluation to diagnose the primary.Chest X-ray,upper gastrointestinal endoscopy ,ultrasound of the neck and breast were normal.Colonoscopy revealed a ulcerated rectal polyp from which biopsy was taken.

Histopathological examination and immunohistochemistry confirmed small cell carcinoma of rectum.

The patient was started on chemotherapy with cisplatin and etoposide.Presently,the patient is responding well to chemotherapy.

\section{DISCUSSION}

Neuroendocrine carcinomas are rare but behave aggressively when arising from colon and rectum.Large bowel small cell carcinomas are very rare in presentation and account for $0.2 \%$ of all large bowel malignancies ${ }^{1,2}$.Only upto 100 cases have been reported in English literature ${ }^{3-6}$. The tumor is thought to derive from pluripotent neuroendocrine stem cells ${ }^{7}$. Etiological factors are not known. While the majority of neuroendocrine tumors are asymptomatic and non functioning and are found incidentally at autopsies ${ }^{8}$.Those diagnosed antemortem may become symptomatic due to local effects or due to systemic effects caused by the hormone/peptide secretion.However,about $75 \%$ of neuroendocrine tumours have metastatic disease at presentation ${ }^{9}$.Pathological characteristics of the tumor are similar to small cell carcinomas at other sites.On histopathological examination,closely packed cells with scanty cytoplasm along with nuclear pleomorphism,high mitotic rate and necrosis are evident.Neuroendocrine differentiation is evident by immunohistochemistry or electron microscopy..The combination of cisplatin and etoposide has been considered the chemotherapeutic regimen of choice presently for metastatic neuroendocrine carcinomas ${ }^{10}$.

Our case had an advanced malignancy at the time of presentation. Hence,we had to resort to palliative chemotherapy with cisplatin and etoposide.The patient has been doing fairly well with slight reduction in liver mass over the past two months.

The median survival in such cases have been reported to be 5 to 11 months $^{3}$.It is quite important in 
terms of survival benefit to catch these tumors at an early stage before its too late like in our case.But,the problem is that majority of these tumors are asymptomatic and are metastatic at the time of presentation.

\section{References}

[1]. Clery AP, Dockerty MB, Waugh JM: Small cell carcinoma of the colon and rectum: A clinicopathological study. Arch Surg 83:164$172,1961$.

[2]. Robidoux A, Monte M, Heppel J, et al: Small-cell carcinoma of the rectum. Dis Colon Rectum 28:594-596, 1984

[3]. Gaffey MJ, Mills SE, Lack EE: Neuroendocrine carcinoma of the colon and rectum: A clinicopathologic, ultrastructural and immunohistochemical study of 24 cases. Am J Surg Pathol 14:1010-1023, 1990.

[4]. Wick MR, Weatherby RP, Weiland LH: Small cell neuroendocrine carcinoma of the colon and rectum: Clinical, histologic and ultrastructural study and immunohistochemical comparison with cloacogenic carcinoma. Hum Pathol 18:9-21, 1987.

[5]. Mills SE, Allen SM, Cohen AR: Small-cell undifferentiated carcinoma of the colon: A clinicopathological study of five cases and their association with colonic adenomas. Am J Surg Pathol 7:643-651, 1983.

[6]. Staren ED, Gould VE, Warren WH, et al: Neuroendocrine carcinomas of the colon and rectum: A clinicopathologic evaluation. Surgery 104:1080-1089, 1988.

[7]. Gladhill A, Hall PA, Cruse JP, et al: Enteroendocrine cell hyperplasia, carcinoid tumours and adenocarcinoma in long-standing ulcerative colitis. Histopathology 10:501-508, 1986.

[8]. Berge T, Linell F. Carcinoid tumours. Frequency in a defined population during a 12-year period. Acta Pathol Microbiol Scand A. 1976 Jul;84(4):322-30. PubMed PMID: 961424.

[9]. Chamberlain RS, Canes D, Brown KT, et al. Hepatic neuroendocrine metastases: does intervention alter outcomes? J Am Coll Surg 2000;190:432-45.

[10]. Mitry E, Rougier P. The treatment of undifferentiated neuroendocrine tumors. Crit Rev Oncol Hematol. 2001;37:47-51. 